\section{HUNGLR THE IRIMITIVIE DLSIRL.}

BY s. V. Cr.kvengek, M. D.

A paper on Researches into the Life History of the Monads by W. H. Dallinger, F. R. M.S., and J. I)rysdale, M. D., was read before the Royal Micrscopical Society; Dec. $3 d, 1873$, wherein tission of the Munad was described as being preceded by the absurption of one form by another. One Monad would fix on the sarcode of another and the substance of the lesser or under one would pass into the upper one. In about two hours the merest trace of the lower one was left and in four hours fission and multiplication of the larger monad began. A full description of this interesting phenomenon may be found in the Ionthly Mitroscopical fournal (London), for October, 1877.

Professor Leidy has asserted that the Amo-ba is a cannibal, whereupon Mr. J. Nichels in the Amiricall Fournal of . Miroscopy, July. $1 \$ 77$. calls attention to I)allinger and 1)rysdale's contribution and draws therefrom the inference that each camnibalistic act of the $\Lambda m(x)$ a is a reproductive one, or copulative, if the term is almissible. The editor (Dr. Henry Lawson), of the English journal, Oct., 1877, agrees with . Nichels.

Among the numerous speculations upon the origin of the sexual appetite, such as Maudsley's altruistic conclusion, which always seemed to me to be far-fetched, I have encountered none that referred its derivation to hunser. At tirst glance such a suggestion seems ludicrous enough, but a little consideration will show that in thus fusing two desires we halle still to get at the meaning and derivation of the primary one-desire for food.

The cannibalistic Am(x) may, as I)allinger's Monad ceraninly does, impregnate its:lf by eating its own kind, and we have innumerable instances among dlgav and Proto\%on of this sexual fesion appeatring very much like ingestion. Crabs have heen seen to confuse the two desires by actually eating portions of each other while cop)ulating, and in a recent n'smber of the sitintific American, a Texan details the drantes relisiosa femaie eating off the head of the male .Mantis during conjugation. Some of the female Arachnider find it necessary (1) tinish the marital repatst be devouring the make, who trie's (o seimper away from his iate. The bitings and even the eme brace of the higher ammals appears to hate reference: to this derivation. It is a physiological het that associatticon often transfers an instinct in an apparently outraecens mamer. With quadrupeds it is undoubtedly olfaction that is most closely relited to sexual desire and its reflexes, but not so in man. Ferrier diligently searches the region of the temporal lobe near its connection with the olfactory nerve for the seat of sexuality, but with the diminished importance of the smeling sense in man the faculty of sight has grown to vicarate oltaction; certainly. the "lust of the eje's" is greitler than that of other special sense organs amonir Bimana.

In all animal life multiplication proseeds from growth, and until a certain stage of growth, puberty, is reached, reproduction does not eccur. The complementary nature of growth and reproduction is obs:rvable in the large size attained by some animals after castration. Could we stop the drision of an .Imereba a complablble increatse? in size would be effected. The groecespereness of these view's is due to their rovelty, not to their beingr unjustitiitble.

While it would thus serm appoutent thatt a primevol

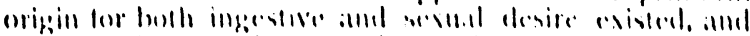

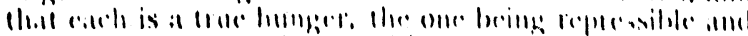

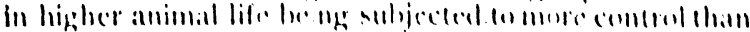
the other, the questimn then presents itsell: Whol is hunger? It requires but little reflection to convince one ot its potency in determining the destinies of nations and individuals, and what a stimulus it is in animated creation. It seems likely that it has its origin in the atomic allinities of inamimale nallure, a view monistic enough to please Haleckel and 'Tyundall.

\section{NOTLS ON THE ANITOMY OF THE ENCE- PHALON, NOTABLY OF THE GREAT GAN-} Gilil.

\author{
Br EUWIRI C. SitT\%KA, M. D.
}

The anatomy of no portion of the brain is so obscure and so imperfectly known as that of the so-called Thalamus opticus. One of the first requisites to a comprehension of its relations is the establishment of a proper nomenclature, and the point to start from is the very name under which the great ganglionic mass is known. since it is not exciusively or even in the main connected with the optic tracts in any animal or man, and, indeed, is in the lower sauropsidit and amphib:ans not connected with them at all, the affix opticus should be dropped, and the tirst word involving that very uncompromising conception of an elevation at the ventricular floor mav be retained: Thalammas.

The current conception that the Thalamus is an elevation at the floor of the lateral ventricle is incorrect. (One of our leacing comparative an:tlomists will shorty review this question, and it will therefore be but necessary for me to refer to the matter.

In the cat's brain it can be clearly seen, that laside from membranous separations, the great mass of the Thalamus is excluded trom the cavity of the lateral ventricle by the fusion of the lateral edgre of the fornix with the corpus striatum, or rather with the ependyma of that ganglion. Consequently, the two thalami are included in the thircl ventricle, which cavity on cross setion resembles an upright $T$, whose vertical branch descends between

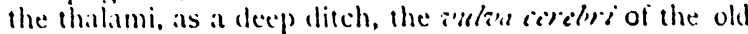
anattomists.'

Luys, who was unfortunately liedeled to certain physiological prejudices as to the function of the thalamicientres, restricted the term Tianlamas to the most external mass. Mernert called all the centres in the agraregate by that term is a collecture desiernation. He excluded. however, that gray mass which line's the sides of the vertical slit of the third rentriele.

Now, the third entricke, as shown by Iladlich and Wilder, extends over the entire thalami: it would be therefore, incorred to limit the designation "central tubular gray of the thitd ventricle:" t) that portion (nily which lines the vertical slit. Either this latter designaltion should be extended to the entire thalamic masse's or the term thalamus should be extended to the so-cialled central tubular gray.

Thus interpreted there would be, strictly speaking. but a single thalamus, consisting of (Ww main masses, and a cummissural part. The commissure is fouble. The thallumi are primitively united by the lower of these commissures, which I propose 10 torm "basilar commissure.": Secondarils, and only in animals above marsupials (as far as $1 \mathrm{am}$ awarel, do we find another commissure produced at an adranced period of embrionic development by apposition of the matrin masses. This is the so-cilled middle commissure of the brain, the commersisum a srisica, c mollis. I should consider the least ambiguous

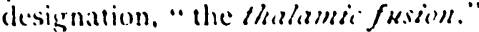

In a manner similar to that which separates the candate and lenticular nuclei from each other, and wheh

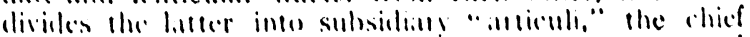

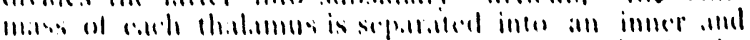

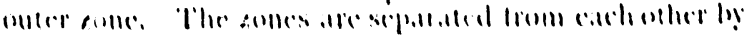

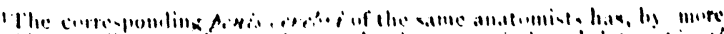

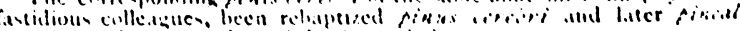

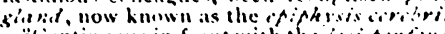

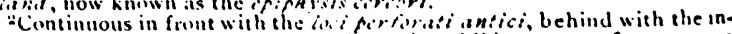
fundibulum. Atruphic over the chiasm, it exhibits a set of transsere fibecis and gray substance clsewhere. 
a white intercalation, and especially the outer zone (also in part the inner) presents a beautiful alternation of gray and white laminz. ${ }^{3}$

I'hese two gray zones constitute the funclamerital demarcation of the thalamus; they may be termed zona grisea medialis and zona grisea lateralis. In animals abuve the rank of marsupials we find added a round noclular mass, distinctly prominent at the ventricular floor, which lies anteriorly, while in still higher groups a second nodular prominence develops posteriorly. The latter is known as the posterior tubercle or pulvinarium, the former as the anterior or snperior tubirile. The former designation seems the best to me, for although what I call the undifferentiated parent mass of the thalami is visible in sections anterior to those in which the anterior tubercle is reached, yet the latter, which I propose to term the antirior nodule of the thalamus, is the tirst differentiated centre reached. In man the zona grisca medealis is faintly seen before the anterior nodule is reached, but the anterior nodule reaches its main deiclopment before the zones do, and is absent where these are most prominent. In the carnivora generally, the anterior nodule projects far in advance of the zones. In these animals, too, a more complex arrangement of this nodule is found than in man, inasmuch as the anterior part of the internal slope of the thalamus shows sereral elevations absent in the human thalamus.

The sona grisea medialis appears pretty equally diffused and exhibits its lamination evenly both in front and in the miclalle of its course. The same applies to the human brain lor the zona grisea laterales. In the cat, $h$ wever, the anterior part of the external zone appears as a beautilul round compact ganglionic mass, protruding boldly into the internal capsule, and which acquires the characteristic lamination only in posterior planes.

It is interesting to note that the ganglionic matter of the thalamus is continuous with that of the ventriculir nucleus of the corpus striatum (nucleus caudatus). Indirectly it is connected with the extra-ventricular nucleus, through. that great common basilar gray mass, which is the rcudizalus, as it were, of all the gray categories of the forebrain. ${ }^{5}$

In an earlier publication (Architecture and Mechanism of the Brain-Journal of Mental and Nerious Diseases, 1879), I have called attention to the fact that the ventricular nucleus of the corpus striatum is the representative of the primordial cerebral gray, inasmuch as the nerve cells of the embryonic and lower amphibian hem:sphere are concentrated immediately subjacent to the ependyma of the latter ventricle. The majority of these cells are crowded away from the ventricular fluor by the white substance developed in higher animals, and only a portion of the primitive gray remain; subependymal. This is precisely what constitutes the corpus striatum. Now the corpus striatum actually lines the ventricle; it not only lies at its floor! Iny section transtersely to the cerebral axis and striking the forepart of the lateral ventricle in the Hippopotamus, Horse, Dog or Cat, will show that an attenuated part of the corpus striatum is continued around wior the ventricle, and constitutes a greater part of its roof.

A similar comparative study shows that the nucleus lenticularis is also a si'xcortical clevelopment, that is, it results from the individualization of a gray mass originally continuous with the cortex, by means of an irruption of white masses. These at first separate fasciculi (as in

3And yet the latest pretended description of these Ciunglia, admitted, notwithetanding numberless glaring errors into a journal of the standing

As seen in a series of transverse sections prepared by Dr. Graeme Hamiond.

'Here meet the olfactory gray, the contex, the basis capitis nuclir culduti, the nuclius lenticularis, the claustrum, the thalamic axial
gray, etc., etc. the dog) in higher animals coalesce to constitute the external capsule. The segmentation of the lenticular nucleus into three distinct articuli so characteristic of the human brain, is not found in the carnivora; only the outer articulus is demarcated, and that but imperfectly.

In the carnivola the laminae medullaris or white streaks of the lenticular nucleus are conspicuously absent in the anterior half of that ganglion; in its posterior half they appear and they rapidly increase in bulk as we proceed backwarils, so that in planes where the human Ienticular nucleus is still quite massive, we have in the dog only slight ganglionic masses intercalated hetween the fibre tracts. The claustrum is, in the carnivora, nct the thin expanded lanina found in man, but a low and massive accumulation, hardly separated from the cortex of the Island of Reil. This fact strengthens Meynert's view that the claustrum is but an individualized cortical lajer.

In conclusion I would mention as an isolated fact, ard disconnected from the main subjects dealt with in these notes, that the anterior pyraricls of the brain of the large Ceylon fruit bat (Pleropus fuligincsus) undergo a superficial decussution, as patent, and more so, as that of the optic chiasm. The pyranidal tract after decussating is continued as a distinct fasciculus on the lateral aspect of the medulla oblongata. In the same brain the tibres of the fornix can be clearly seen to terminate in the thalamus without descending to the base of the brain. Whether this applies to the whole of that tract, I am not able to sity.

I would also note that in the brain of a large Ara (Ara ararauna) obtained from the Superintendent of the Central l'ark Zoological Gardens, Mr. IW. A. Conklin, I four:d what appeared to be a thin commissure uniting the two cerebral hemispheres in their posterior halt. This (commissure! if the observattion was ccrrect) was not, like the corpus callosum, a connection between the internal white matter of both hemispheres, but merely a union of the superticial white, which in lower animals is welldereloped outside of the contical gray.

In the carmicara the cianslion of Soenmering (the iubstantia nigra in the human brain) is continuous with the innermost part of the lenticular nucleus. This fact strengthens .lleynert's propusition, that the (ianglion of Socmmering, like the caudatc and lenticular nuclei, should be considered as paris of one system, whose ganglia are connected with the fibres of the pis pidunculi.

In the elephant. Whose brain, both in its mass, the preponderance of the hemispheres, and the concealnient from view of the so-called "trapezium," takes a high rank as iegards the grade of development. I had the opportunity to make and examine transterse microscopic sections from the Pons V'arolii. The remarkable discovery was made that the descending (longitudinal) tibres of the Pons are wanting. Nothing but transterse fasciculi are seen in the: field. Since the former fibres constitute part of the pyramidal tract, it follows that the tract of the voluntary impulses, the "will-tract," must take anuther course in the elephant, one which may be considered aberrant; for in all other placental animals so far examined by myself, the pyramidal tract runs through the Pons Varolii, as in man.

ON W.ntrixe. - Waldivine, $\mathrm{C}_{30} \mathrm{H}_{24} \mathrm{O}_{20}$, is a neutral principle, without rotatory power, very sparingly soluble in cold water, frecly soluble in chloroform, insoluble in ether, and remarkable for the ease with which it is decom posed by alkalies.

Certix Ormical axil Vistal. Phenomena-If the tlame of a lamp is viewed throuph a narow slit, the lustre of the f!ame and the efiects of difiraction vary much according as the slit is vertical or horizontal, the light being much more considerably in the latter case. - M. TREve. 


\section{Science}

\section{NOTES ON THE ANATOMY OF THE ENCEPHALON, NOTABLY OF THE GREAT GANGLIA}

Edward C. Spitzka

Science os-2 (30), 14-15.

DOI: $10.1126 /$ science.os-2.30.14-a

ARTICLE TOOLS

http://science.sciencemag.org/content/os-2/30/14.2.citation

PERMISSIONS

http://www.sciencemag.org/help/reprints-and-permissions

Science (print ISSN 0036-8075; online ISSN 1095-9203) is published by the American Association for the Advancement of Science, 1200 New York Avenue NW, Washington, DC 20005. 2017 (C) The Authors, some rights reserved; exclusive licensee American Association for the Advancement of Science. No claim to original U.S. Government Works. The title Science is a registered trademark of AAAS. 